\title{
Diagnosis and control of chicken coccidiosis: a recent update
}

\author{
Abiodun Joseph Fatoba ${ }^{1} \cdot$ Matthew Adekunle Adeleke ${ }^{1}$
}

Received: 5 May 2018/Accepted: 24 October 2018/Published online: 29 October 2018

(C) Indian Society for Parasitology 2018

\begin{abstract}
Coccidiosis is a deadly disease that hampers chicken's productivity and welfare. Thus, the disease is a major menace to the global poultry industry. Coccidiosis which is caused by the apicomplexan parasite of the genus Eimeria has seven known species which affect the different parts of the intestinal tract of chickens. The disease which occurs by ingestion of sporulated oocyst has been associated with poor poultry management system. Mixed infection among the species of this parasite contributes to both pathogenicity and misdiagnosis of the disease. A progress in identification and diagnosis approach which cuts across pathological, morphological and molecular has been reported for this parasite. Control measures which include anticoccidial drugs, vaccines and natural products have dominated literature for this disease. However, the emergence of genetic and antigenic diversity with implication on resistance to anticoccidials among different strains of Eimeria parasite has generated concerns on the effectiveness of the current anticoccidial vaccines. A new look on the control strategy therefore becomes imperative. This study reviews the current trends on the identification and control of chicken coccidiosis with focus on (1) Avian coccidiosis (2) Epidemiology of chicken coccidiosis (3) Eimeria parasite and distribution in poultry (4) Diagnosis of Eimeria parasite (5) Control measures of coccidiosis (6)
\end{abstract}

Abiodun Joseph Fatoba and Matthew Adekunle Adeleke have contributed equally.

Matthew Adekunle Adeleke

adelekem@ukzn.ac.za

1 Discipline of Genetics, School of Life Sciences, College of Agriculture, Engineering and Science, University of KwaZulu-Natal, Westville, P/Bag X54001, Durban 4000, South Africa
Threats posed by genetic and antigenic diversity of Eimeria parasite on coccidiosis control. Genomic study on diversity of Eimeria parasite becomes imperative for effective vaccine design against coccidiosis.

Keywords Anticoccidial · Chicken · Coccidiosis · Eimeria $\cdot$ Parasite

\section{Introduction}

Over the decades, the world has been experiencing a continuous growth in human population. According to UN DESA (2017), the current human population of 7.6 billion has been projected to a population of 9.8 and 11.2 billion respectively by 2050 and 2100 . To meet this ever-growing population, food, shelter and clothing become imperative. Food production carries a larger percentage of these basic human needs as its availability determines the existence of human population (Erb et al. 2012). In view of this, much demand has been on the agricultural sector of each nation to increase food production that is safe for human consumption that will meet the ever-growing population.

Poultry industry is one of the fastest growing sub-sector of agriculture that contributes to global nutrition (Mottet and Tempio 2017) and thus a major driving force of the economy. Chicken, a major poultry bird contributes greatly to agricultural production through the supply of meat and eggs (Hald 2010). However, chickens are also host to many deadly diseases which hamper on productivity and compromise welfare resulting in high mortality in some cases. Among many diseases that affect chickens globally, coccidiosis is a house-hold name associated with high level of mortality in poultry industry (Blake and Tomley 2014). 
Chicken coccidiosis is an enteric disease that impairs growth and suppresses the immune system resulting in high mortality which has been estimated to cost more than US\$3billion annually in poultry industry (Blake and Tomley 2014). The disease is caused by a protozoan apicomplexan parasites of genus Eimeria which consist of over 1000 species (Blake 2015).

In chicken, seven species of Eimeria have been identified among which E. tenella, E. maxima and E. acervulina have been regarded as the most economically significant species (Thenmozhi et al. 2014). Co-infection of Eimeria species (Haug et al. 2008; Jenkins et al. 2008) is common in coccidiosis which contributes not only to pathogenicity but also leads to misleading diagnosis.

Identification of Eimeria species is important as it provides the bedrock for effective control measure. Morphological approach based on examination of oocyst by microscope and some parasitological parameters were the first-generation approach used in the identification of Eimeria species (Long and Joyner 1984). However, several limitations such as complexity, expertise and confusing characteristics among species have reduced the efficacy of this method (Kawahara et al. 2010). This has given room for molecular approach.

The control measure against this parasite has been through the use anticoccidial drugs, vaccines and strict management practice (Godwin and Morgan 2015). However, the emergence of resistant strains has threatened the effectiveness of these anticoccidials necessitating a modification in the present control method.

This review summarized the recent trends in the diagnosis and control of Eimeria parasite in chickens viz-a viz; avian coccidiosis, epidemiology of chicken coccidiosis, Eimeria parasite and distribution in poultry, identification and diagnosis of Eimeria parasite, control measures of coccidiosis and threats posed by genetic and antigenic diversity of Eimeria parasite on coccidiosis control.

\section{Avian coccidiosis}

Among parasitic diseases that affect the poultry industry, coccidiosis is renowned as a dreadful disease that causes economic loss. It is caused by Eimeria species of the phylum apicomplexa. Over 1000 species of Eimeria have been reported to infect different host animals such as chicken, duck, turkey, cattle, rabbit, sheep and domestic dog and cat (Blake 2015). In chicken, seven species have been described which are E. tenella, E. maxima, E. mitis, E. acervulina, E. brunetti, E. praecox, and E. necatrix. The level of lesion caused by these species in different area of the gut is associated with their level of pathogenicity (Morris et al. 2007).
Eimeria oocyst is the main cause of coccidiosis which get into chickens via ingestion of food, water and litter contaminated with oocyst (Shivaramaiah et al. 2014). The oocyst which grows on the fecal shed by infected birds can also be transported to the chicken house through personnel that move from house to house (Belli et al. 2006). The conditions under which most broilers and other birds that are commercially reared for meat grow also contribute to the easy spread of the disease.

Coccidia oocyst is a thick wall which is resistant to both mechanical and chemical damage coupled with proteolytic degradation (Mai et al. 2009). The infective ability of oocyst is due to its ability to sporulate. Sporulated oocysts are infectious while unsporulated oocysts are not (Lal et al. 2009). The sporulated oocyst can survive outside its host for 602 days while unsporulated oocysts can survive for about 7 months in the ceacum of their host (Quiroz-Castañeda and Dantán-González 2015). The thick wall of the oocyst has been associated with its bilayer structure which is composed of lipid and protein. The protein layer has been reported to provide the oocyst with great stability against extreme cold and heat while the lipid layer provides cushion against chemical damage (Belli et al. 2006).

\section{Epidemiology of chicken coccidiosis}

Coccidiosis disease is promoted by poor housing and management system of poultry (Musa et al. 2010). The disease is more rampant in the intensive deep litter system. This kind of system does not only support the breeding of oocyst but also increases the incidence of infection among chickens. Coccidia oocyst sporulate under warmth condition of about $25-30{ }^{\circ} \mathrm{C}$ with adequate aeration and water while dry condition at $10^{\circ} \mathrm{C}$ delays sporulation (Mohammed and Sunday 2015). Coccidiosis affects chicken of all ages, but the infection begins at younger age when the immune system is immature. The disease affects both the intestine and caecum with incubation period of 5-6 days respectively (Musa et al. 2010). Coccidia infection outbreak occurs when chicks ingest large quantities of sporulated oocyst. Reduced food intake, bloody diarrhea and loss of weight are some of the symptoms associated with infected birds (Blake 2015). The severity of the disease is dependent on the number of Eimeria species that co-infect the birds. Among the seven species of Eimeria that infect chickens, E. tenella, E. brunetti, E. maxima and $E$. necatrix have been reported as highly pathogenic while E. praecox is the least pathogenic (Jadhav et al. 2011; Nematollahi et al. 2008). Coccidia oocysts are shed by infected chickens through their fecal droppings and these contaminate water, food and soil (Gharekhani et al. 2014). 


\section{Eimeria parasite and distribution in poultry}

Among different diseases that infect poultry, parasitic diseases also play a key role especially among village chickens. Examples of common poultry parasites include; mites, lice, ticks, helminths, fleas and coccidia. Most poultry birds are infected by more than one intestinal parasite type and this also contributes to their wide distribution (Poulsen et al. 2000; Sandhu et al. 2009).

The prevalence of Eimeria parasite has been reported among different farms in various geographical region by several studies (Sultana et al. 2017; Györke et al. 2013; Gharekhani et al. 2014; Mohammed and Sunday 2015). Recent studies by Malatji et al. (2016) reported the prevalence rate of $29.46 \%$ of Eimeria parasite among local chickens of Limpopo and KwaZulu-Natal of South Africa. Mortality rate of 54.3, 31.7, 70.9 and $52.9 \%$ associated with Eimeria parasite have been reported in Turkey, India, Ethiopia and Nigeria respectively (Karaer et al. 2012; Sharma et al. 2009; Oljira et al. 2012 and Muazu et al. 2008)

Eimeria infection in chickens are due to co-infection of different Eimeria species and this causes mild to severe lesion (Jenkins et al. 2008). Different sites of the gastrointestinal tract are habited by specific chicken Eimeria species i.e.: E. acervulina develops in the duodenum, $E$. maxima and E. mitis grows in the middle of small intestine while E. tenella, E. brunetti and E. necatrix grows in the caeca, rectum and small intestine. The prevalence of Eimeria infection in chickens has also been reported to be influenced by favourable weather condition and the poultry management system (Etuk et al. 2004).

\section{Identification and diagnosis of Eimeria parasite}

Prior to the advent of molecular methods, traditional methods such as cross-immunity, characteristics lesions, site of development and pathogenicity were used in the identification of Eimeria species (Singla and Gupta 2012). However, the methods are time consuming, labour intensive and require high level of expertise (Shirley et al. 2005). Pathological and morphological analysis such as lesion site, oocysts shape and size could be used to confirm the presence of coccidiosis but the identification of precise Eimeria species is needful for the control of the disease as it reveals the level of resistance either to drug or vaccine (Lee et al. 2010). Although this method is still currently in use, they are complemented with molecular methods in most research.

Alternative method to the traditional method is the introduction of computational method called COCCIMORPH which uses oocyst morphology in the identification of Eimeria species (Castañón et al. 2007). Among the parameters which the software uses in the identification of Eimeria species include; curvature, geometry and texture. Kumar et al. (2014) reported corresponding agreement of COCCIMORPH with nested PCR-ITS- 1 as they were both effective with $E$. acervulina and $E$. mitis though the computational approach was less sensitive to E. brunetti, $E$. tenella and E. praecox.

Molecular method uses PCR assay by amplification of specific gene in the DNA sequences of Eimeria parasite. ITS- 1 and ITS-2 are sequences which are excised from rDNA precursor through post transcription. They have been widely used in the identification of all the seven species of Eimeria in chickens using specific primers (Haug et al. 2007, 2008; Hamidinejat et al. 2010; Jenkins et al. 2006). Although Lew et al. (2003) reported significant variation among E. maxima isolates of different samples indicating the use of two distinct primers for this species, ITS-1 is highly sensitive due to high number of rDNA repeats and provides diagnostic tool for accurate identification of Eimeria species in turkey and rabbit (Vrba et al. 2010; Cook et al. 2010; Oliveira et al. 2011). Targeting primers at conserved ribosomal DNA sequences (5.8S and 28S) have also been used in Eimeria species identification with high level of genetic variants (Morris et al. 2007; Cantacessi et al. 2008).

In addition to the use of ITS-1 and ITS-2, Random Amplified Polymorphic DNA (RAPD) have been used to develop Sequence Characterized Amplified Region (SCAR) primers for the identification of each Eimeria species (Fernandez et al. 2003). These primers have been tested for the amplification of Eimeria species. Fernandez et al. (2003) combined the SCAR primers for the seven species of Eimeria for the development of multiplex PCR assay which are used for simultaneously discrimination of all species of Eimeria infecting chickens in a single tube reaction. SCAR markers have since then been used by various studies in the detection of Eimeria species (Carvalho et al. 2011, Ogedengbe et al. 2011, Blake et al. 2008). The limitation of SCAR method is that it may be less sensitive as compared to ITS- 1 and ITS-2 which are present in the multiple copies of Eimeria genome (Vrba et al. 2010).

To corroborate this, Kumar et al. (2014) compared different three PCR protocols for the identification of Eimeria species vis-à-vis nested PCR-ITS-1, Multiplex SCAR PCR in one tube and two tube reaction. The study confirmed the sensitivity of nested PCR- ITS-1 for Eimeria species identification while better result was also reported in multiplex SCAR PCR in two tube reaction as compared to one tube. The use of nested PCR-ITS-1 for the identification of Eimeria species has been employed in different studies (Lew et al. 2003; Kumar et al. 2015) though the protocol is not without its own limitation such as the time, 
cost and complexity associated with the use of two PCR steps (Kumar et al. 2014).

Despite the contribution of PCR-based method in the identification of Eimeria species, the limitation of this assay is the difficulty associated with extraction of DNA from the Eimeria oocyst. Eimeria oocyst processed from fecal samples are resistant to chemical agents and thus their disruption becomes imperative for quality DNA. Different chemical agents for oocyst disruption have been reported (Zhao et al. 2001; Haug et al. 2007; Carvalho et al. 2011).

Beyond the use of PCR-based method, quantitative assay such as real-time PCR (qPCR) amplification of ITS1, ITS-2 and SCAR markers have been used in different studies to identify Eimeria species (Blake et al. 2008; Kawahara et al. 2008). Lalonde and Gajadhar (2011) reported that a qPCR assay with melting curve analysis and primers conserved in various protozoa could detect $E$. acervulina in a mixture of oocyst. Similarly, the study of Kirkpatrick et al. (2009) confirmed the identification of all the seven species of Eimeria from pure oocysts cultures using a high-resolution melting curve analysis with a qPCR directed at ITS-1 sequences. The cost associated with this assay has limited its routine application.

To minimize cost associated with molecular methods in Eimeria species identification, Loop-mediated Isothermal amplification (LAMP) has been developed as alternative approach (Barkway et al. 2011). The presence of isothermal enzymes and intercalating dyes in this technology means that reaction can be run without the use of thermocycler and electrophoresis. This has given the technology an edge over other molecular methods. Different studies on the use of LAMP assay for apicomplexan parasites detection has been reported (Karanis et al. 2007; He et al. 2009; Thekisoe et al. 2010; Sun et al. 2017). However, this technology still need much improvement for it to be a standard assay.

Despite the wide use of ITS-1 and ITS-2 in Eimeria identification, the only drawback is the intraspecific and intragenomic variations that exist in these genes which contribute to their poor species delineation. In view of this, Ogedengbe et al. (2011) described cytochrome c oxidase subunit 1 (COI) as highly effective in species delineation of different organism including Eimeria. Different studies on the use of COI in the identification of Eimeria species have been reported (Schwarz et al. 2009; Hafeez et al. 2016; Rathinam et al. 2015; Ogedengbe et al. 2018). The only limitation of this gene in species identification is that it has few reference sequences in the public data. Therefore, combination of multiple locus such as ITS and COI is a new approach currently being explored for the identification of Eimeria species.

\section{Control measure of coccidiosis}

Due to drastic effect of coccidiosis on the poultry, different control methods have been deployed. Thorough biosecurity coupled with the use of prophylactics were the first strategies deployed in the control of this disease. Synthetic drugs (Table 1) such as amprolium, nicarbazin, diclazuril, and toltrazuril were used effectively to control coccidiosis disease in poultry for many years (Shivaramaiah et al. 2014). The drugs target the sporozoite/merozoite developmental stage of the parasite. However, the constraint of this strategy in the control of coccidiosis disease is the emergence of drug resistant isolates of Eimeria parasite (Peek and Landman 2011). High percentage of field isolate of E. acervulina and E. maxima couple with E. tenella obtained from 28 farms in 12 states of the United State showed partial or complete resistance to renowned synthetics drugs-nicarbazin and narasin (Bafundo et al. 2008). Public pressure to reduce drugs in the food chain has led to search for alternative strategy to the control of coccidiosis (Peek and Landman 2011).

Among the alternative measures explored is the use of natural products (Table 2) which include probiotics, plant extracts and fungal extracts. Probiotics is the use of bacteria as feed to improve the immune system of the chicken against infection. Dalloul et al. (2005) reported the effectiveness of Lactobacillus-based probiotics, Primalac which reduced the oocyst shedding and increase $\mathrm{T}$ and $\mathrm{B}$ cellspecific cytokine against $E$. avervulina infection. In a similar manner, the study of Lee et al. (2007) confirmed the effectives of Pediococcus-based probiotics in improving performance against $E$. acervulina and E. tenella infection. Since then, a consistent report on the use of probiotics either alone or together with other supplements has been confirmed to reduce microscopic lesion in birds infected with coccidiosis (Chen et al. 2016; Ritzi et al. 2014).

Similarly, significant reduction in the mortality of birds infected with coccidiosis has been reported among different plant extracts (Drăgan et al. 2014; Gholamrezaie Sani et al. 2013; Habibi et al. 2016; Nghonjuyi et al. 2015). The antimalaria 'artemisinin' derived from the herb Artemisia annua has been reported to have damaging effects on the macrogametocyte of E. tenella by limiting the expression of sarcoplasmic-endoplasmic reticulum calcium ATPase enzyme (del Cacho et al. 2010). Increase body-weight and reduced lesion scores are some of the advantages of plants extracts reported in these studies. As against the background of rearing birds in a controlled environment before infecting them with Eimeria parasite, Chang et al. (2016) recently evaluated the field trial anticoccidial efficacy of Bidens pilosa in broiler chickens. The study confirmed increased body-weight, reduced lesion scores, decreased oocyst per gram of feaces in birds with feed supplemented 
Table 1 Summary of the anticoccidial drugs used in the control of Eimeria species

\begin{tabular}{|c|c|c|c|c|c|c|}
\hline Drugs & $\begin{array}{l}\text { Target } \\
\text { species }\end{array}$ & Dosage & M I & M A & Effects & References \\
\hline Monensin & All spp & $0.01-0.121 \%$ & PI & Increased intracellular $\mathrm{Na}^{+}$ & Attack 1st generation schizont & $\begin{array}{l}\text { Smith and } \\
\text { Galloway (1983) }\end{array}$ \\
\hline Amprolium & Et, En, Ea & $0.0125 \%$ & PI & Blocks thiamine receptors & $\begin{array}{l}\text { Suppression of sexual stages and } \\
\text { oocyst }\end{array}$ & James (1980) \\
\hline Nicarbazine & All spp & $0.0125 \%$ & PI & $\begin{array}{l}\text { Disrupt intracellular energy- } \\
\text { supplying ATP }\end{array}$ & $\begin{array}{l}\text { Inhibit } 1 \text { st generation Schizont and } \\
\text { sexual stages }\end{array}$ & Wang (1978) \\
\hline Sulphaquinoxaline & $\mathrm{Ea}, \mathrm{En}, \mathrm{Et}$ & $0.025-0.033 \%$ & $\begin{array}{l}\text { PI, } \\
\text { TP }\end{array}$ & Inhibit folate synthesis & Inhibit schizogony & $\begin{array}{l}\text { Grumbles et al. } \\
\text { (1948) }\end{array}$ \\
\hline Ethopabate & $\begin{array}{l}\mathrm{Em}, \mathrm{Eb}, \\
\mathrm{Ea}\end{array}$ & 4-40 ppm & PI & Inhibit folate synthesis & $\begin{array}{l}\text { Disrupt development on the } 4 \text { th } \\
\text { day of cycle }\end{array}$ & Rogers et al. (1964) \\
\hline Quinolones & All spp & $3 \times 10^{-6} \mathrm{M}$ & PI & Disrupt electron transport & Hinders sporozoite development & Wang (1976) \\
\hline Robenidine & All spp & $0.0066 \%$ & PI & $\begin{array}{l}\text { Inhibit oxidative } \\
\text { phosphorylation }\end{array}$ & $\begin{array}{l}\text { Hinder growth of 1st generation } \\
\text { schizont }\end{array}$ & Wong et al. (1972) \\
\hline
\end{tabular}

PI Prophylactic, TP Therapeutic, M.A Mechanism of action, M.I Method of introduction, Ea Eimeria tenella, En E. necatrix, Ea E. acervulina, Em E. mitis

with $0.025 \%$ of $B$. pilosa. The combined use of plant extracts and probiotics as anticoccidial has also been reported (Djezzar et al. 2014). Despite the success reported by plant extracts, little understanding about their mode of action and the concern on their safety and toxicity has limited their commercial usage.

For decades, vaccine has been used for the control of coccidiosis. Live non-attenuated vaccines which have a virulence has been proven effective against this disease (Shirley 1992). The first commercially produced live nonattenuated anticoccidial vaccine CocciVac and its variants CocciVac-B, CocciVac-D and Immucox have been highly successful and are still in use today (Jenkins et al. 2012; Milbradt et al. 2014). However, the risk of disease outbreak of these vaccines led to attenuated vaccines (Quiroz-Castañeda and Dantán-González 2015).

The virulence of attenuated anticoccidial vaccine is usually reduced. This is done by screening for more precocious Eimeria isolate i.e. isolates with shortened prepatent period due to lack of one or more secondary schizogony compared to the Eimeria strain with normal life-cycle (Mathis et al. 2017). Although attenuated anticoccidial vaccines are still much in use today, their low degree of immune protection has called for their use with adjuvants (Ahmad et al. 2016). This has given room to recombinant and sub-unit vaccines.

Recombinant anticoccidial vaccines make use of Eimeria species antigens that have immunogenic properties to trigger effective immune response. However, the genetic diversity of this vaccine antigens and the inefficiency of the vaccine to tackle co-infection of Eimeria species has led to various modification of recombinant vaccines. Song et al. (2015a) reported the efficacy of multivalent epitope DNA vaccines against coccidiosis in chicken. The vaccine which was made up of four most effective T-cell epitopes of each Eimeria species antigen increased body weight gain, alleviated enteric lesion, reduced oocyst produced by infected birds and triggered anti-coccidial index of more than 170 against E. tenella, E. acervulina, E. maxima and E. necatrix (Song et al. 2015a). In a similar way, multivalent sub-unit vaccine which consists of recombinant antigens from four species of Eimeria (E. tenella, E. acervulina, E. maxima and E. necatrix) has been reported to provide partial protection against coccidiosis caused by these species (Song et al. 2015b). Different studies on the use of vaccines in the control of coccidiosis in chickens have been reported (Huang et al. 2015; Yin et al. 2015).

To further combat the menace of coccidiosis and reduce resistance to the control methods, different strategies such as shuttle and rotation programme have been employed. This entails the combination of different drugs (synthetic or ionophores) of different mode of actions. This has increase the effectiveness of anticoccidial drugs but has no control over the emergence of resistance among the parasite species (Lee et al. 2009). Similarly, (Stringfellow et al. 2011) suggested a combined strategy of proper and uniform vaccine administration couple with boosting the intestinal tract of younger birds with pathogen-free microbiota. Recent study also reported increased body weight and decreased lesion scores among birds treated with both vaccines and water-applied probiotics (Ritzi et al. 2016). 
Table 2 Summary on the use of natural products and its modification as anticoccidial against chicken coccidiosis

\begin{tabular}{|c|c|c|c|c|c|c|}
\hline Natural products & M. A & Extract & Target spp & Dosage & Effects & References \\
\hline \multicolumn{7}{|l|}{ Plant extracts } \\
\hline Aloe vera & Unknown & Ethanol & Em & $0.1-0.5 \%$ & $\begin{array}{l}\text { Decreased lesion scores, decreased } \\
\text { Fecal oocyst shedding }\end{array}$ & Yim et al. (2011) \\
\hline Moringa oleifera & Unknown & Acetone & mixed spp & $1-5 \mathrm{~g} / \mathrm{kg}$ & Increased BWG, decreased OPG & $\begin{array}{l}\text { Ola-Fadunsin and } \\
\text { Ademola (2013) }\end{array}$ \\
\hline Bidens pilosa & Unknown & Powder & All spp & $0.025 \%$ & $\begin{array}{l}\text { Increased BWG, decreased FCR, } \\
\text { decrease OPG }\end{array}$ & Chang et al. (2016) \\
\hline Emblica officinalis & Unknown & Tannin & mixed spp & $0.5-1 \mathrm{mg} / \mathrm{kg}$ & Decreased OPG, increased BWG & Kaleem et al. (2014) \\
\hline Artemisia аппиа & $\begin{array}{l}\text { Produces } \\
\text { reactive } \\
\text { OFR }\end{array}$ & Artemisinin & Et, Ea & $2-17 \mathrm{ppm}$ & $\begin{array}{l}\text { Increased BWG, decreased lesion } \\
\text { score }\end{array}$ & Bozkurt et al. (2013) \\
\hline Musa paradisiaca & Unknown & Methanol & Et & $1000 \mathrm{mg} / \mathrm{kg}$ & Decreased OPG & $\begin{array}{l}\text { Anosa and Okoro } \\
\text { (2011) }\end{array}$ \\
\hline N. tripedale & Unknown & Ethanol & All spp & $30 \mathrm{mg} / \mathrm{kg}$ & Decreased OPG, increased BWG & Habibi et al. (2016) \\
\hline Biarum bovei & Unknown & Ethanol & Et & $30 \mathrm{mg} / \mathrm{kg}$ & Decreased mortality, decreased OPG & Habibi et al. (2016) \\
\hline T. violacea & Unknown & Acetone & All spp & $30 \mathrm{mg} / \mathrm{kg}$ & Decreased OPG, increased FCR & Naidoo et al. (2008) \\
\hline \multicolumn{7}{|l|}{ Probiotics } \\
\hline B. animalis + & Unknown & NA & $\mathrm{Ea}, \mathrm{Em}, \mathrm{Et}$ & $\begin{array}{l}5 \times 10^{8} \mathrm{cfu} / \\
\mathrm{kg}\end{array}$ & Increased BWG & $\begin{array}{l}\text { Giannenas et al. } \\
\text { (2014) }\end{array}$ \\
\hline $\begin{array}{l}\text { L. salivarius }+ \\
\text { E. faecium }\end{array}$ & & & & & Decreased lesion score & \\
\hline B. animalis + & Unknown & NA & $\mathrm{Ea}, \mathrm{Em}, \mathrm{Et}$ & $\begin{array}{l}5 \times 10^{8} \mathrm{cfu} / \\
\quad \mathrm{kg}\end{array}$ & Decreased OPG & Ritzi et al. (2014) \\
\hline $\begin{array}{l}\text { L. salivarius }+ \\
\text { E. faecium }\end{array}$ & & & & & Decreased lesion scores & \\
\hline \multicolumn{7}{|l|}{ Probiotics } \\
\hline Primalac & Unknown & NA & $\mathrm{Ea}$ & $1 \mathrm{~g} / \mathrm{kg}$ & Partial reduction in OPG & Dalloul et al. (2005) \\
\hline $\begin{array}{l}\text { L. fermentum }+ \\
\text { L. plantarum }+ \\
\text { E. faecium }\end{array}$ & Unknown & NA & Et & $10^{9} \mathrm{cfu} / \mathrm{kg}$ & $\begin{array}{l}\text { Decreased lesion scores } \\
\text { Increased RWG }\end{array}$ & Chen et al. (2016) \\
\hline \multicolumn{7}{|c|}{ Probiotics + herbal extracts } \\
\hline $\begin{array}{l}\text { P. acidilactici }+ \\
\text { Y. schidigera }+ \\
\text { T. foenum graecum }\end{array}$ & Unknown & NA & All spp & $\begin{array}{l}10^{9} \mathrm{cfu} / \mathrm{g} \\
0.5 \mathrm{~kg} / \mathrm{t}\end{array}$ & $\begin{array}{l}\text { Increased BWG } \\
\text { Decreased lesion scores }\end{array}$ & Djezzar et al. (2014) \\
\hline Probiotics + vaccine & & & & & & \\
\hline $\begin{array}{l}\text { LBEP }+ \text { immucox } \\
\text { I }\end{array}$ & Unknown & NA & $\begin{array}{l}\text { Ea, Em, En, } \\
\text { Et }\end{array}$ & $\begin{array}{c}20 \mathrm{mg} / \mathrm{bird} \\
0.5 \mathrm{~mL}\end{array}$ & $\begin{array}{l}\text { Increased BWG, decreased lesion } \\
\text { scores }\end{array}$ & Ritzi et al. (2016) \\
\hline
\end{tabular}

Et Eimeria tenella, Em Eimeria mitis, Ea Eimeria acervulina, En Eimeria necatrix, spp species, NA Not applicable, OPG Oocyst per gram, $B W G$ Body weight gain, $R W G$ Relative weight gain, FCR Feed conversion ratio, OFR Oxygen Free Radical, M.A Mechanism of action, Probiotics (L, $B, E$ and $P$ ) Lactobacillus; Bifidobacterium; Enterococcus; Pediococcus, Herbal $(Y, T)$ Yucca; Trigonella

\section{Threats posed by genetic and antigenic diversity of Eimeria parasite on coccidiosis control}

The emergence of anticoccidial-resistant Eimeria species has not only heightened the public concern about this parasite but has also led to consistent modification in the control measure and strategy against coccidiosis. Genetic diversity among Eimeria species as shown in Table 3 is a potential contributor to Eimeria resistance to anticoccidial.

Genetic diversity entails the emergence of new variants among the species of Eimeria. Different approaches such as single or multilocus sequence typing, restriction fragment length polymorphism (PCR-RFLP), amplified fragment length polymorphism (AFLP) and random amplified 
Table 3 Update on the incidence of genetic diversity of Eimeria species in chickens

\begin{tabular}{|c|c|c|c|c|c|}
\hline Eimeria variant & Location & Types of flock & Assay & $\begin{array}{l}\text { Occurrence } \\
(\%)\end{array}$ & References \\
\hline $\begin{array}{l}\text { OTUx, OTUy, } \\
\text { OTUz }\end{array}$ & Australia & $\begin{array}{l}\text { Commercial and } \\
\text { backyard }\end{array}$ & DNA PCR-CE & $33 \%$ & $\begin{array}{l}\text { Godwin and Morgan } \\
\text { (2015) }\end{array}$ \\
\hline $\begin{array}{l}\text { OTUx, OTUy, } \\
\text { OTUz }\end{array}$ & Australia & $\begin{array}{l}\text { Commercial and } \\
\text { backyard }\end{array}$ & Mt genome & NE & $\begin{array}{l}\text { Morgan and Godwin } \\
\text { (2017) }\end{array}$ \\
\hline $\begin{array}{l}\text { OTUx, OTUy, } \\
\text { OTUz }\end{array}$ & Australia & Commercial & nu rDNA (ITS-2) & NE & $\begin{array}{l}\text { Cantacessi et al. } \\
\text { (2008) }\end{array}$ \\
\hline $\begin{array}{l}\text { OTUx, OTUy, } \\
\text { OTUz }\end{array}$ & North-Western Nigeria & Commercial & $\begin{array}{l}\text { Nested species specific PCR } \\
\quad \text { (ITS-1) }\end{array}$ & $33 \%$ & Jatau et al. (2016) \\
\hline OTUx, OTUz & Ghana, Tanzania And Zambia & Commercial & $\begin{array}{l}\text { PCR-rDNA (5S, ITS-1, ITS- } \\
\text { 2) }\end{array}$ & NE & Fornace et al. (2013) \\
\hline $\begin{array}{l}\text { OTUx, OTUy, } \\
\text { OTUz }\end{array}$ & $\begin{array}{l}\text { Africa, Asia, Europe America, } \\
\text { Australia }\end{array}$ & Commercial & $\begin{array}{l}\text { PCR-rDNA (5.8S, ITS-1, } \\
\text { ITS-2) }\end{array}$ & $11.45 \%$ & Clark et al. (2016) \\
\hline
\end{tabular}

OTU Operational Taxonomic Units, NE Not evaluated, $n u$ nuclear, ITS Internal Transcribed Spacers, PCR-CE Polymerase Chain Reaction Capillary Electrophoretic

polymorphic DNA (RAPD) and variable number tandem repeat (VNTR) have unraveled the differences among Eimeria species isolates from various regions (Ogedengbe et al. 2011; Blake et al. 2011; Lim et al. 2012; Pegg et al. 2016).

Recent study by Tan et al. (2017) reported genetic diversity among eight $E$. tenella isolates from different region of Hubei China and this formed two branched cluster based on their geographical distribution with phylogenetic branch length of 0.49-0.75.

Moreover, the report of Blake et al. (2015) indicated genetic diversity and population structure among E. tenella in different regions- India, Egypt, Libya and Nigeria. The author also indicated low level of haplotypes among $E$. tenella in northern India (Haryana, Punjab, Utterak-hand and Uttar Pradesh) as compared with southern India (Kerala, Karnataka, Andhra Pradesh and Tamil Nadu) with high and unique haplotypes.

Exploring the risk factors associated with coccidiosis, Prakashbabu et al. (2017) reported diversity in the distribution of Eimeria species according to poultry unit size, management and system within and between northern and southern India.

Further comparative study into Internal Transcribed Spacer (ITS-1 and ITS-2) sequences of Eimeria has shown three Operational Taxonomic Units (OTUx, OTUy and OTUz) which share similarity with some known species of Eimeria (Godwin and Morgan 2015). These OTUs have been reported to be abundant in some geographical regions but their spread to other regions is a concern as they could limit the effectiveness of current live vaccines.

Similarly, apical membrane antigen 1(AMA-1) has been reported as protective antigen in sub-unit vaccine development against myriads of apicomplexan parasites including E. tenella, E. maxima and P. falciparum (Blake et al. 2011; Drew et al. 2012; Jiang et al. 2012). As against the background of allelic polymorphism among AMA-1 which has limited their use in P. falciparum, AMA-1 is a potential candidate for $E$. tenella vaccine due to its inhibitory capacity on parasite invasion (Jiang et al. 2012). Although low level of allelic polymorphism has been reported among AMA-1 of E. tenella and E. maxima, in vivo studies have also shown some degree of strainspecific immune escape (resistance) among the vaccine candidate for E. tenella, E. acervulina and E. maxima (Awad et al. 2013; Healer et al. 2004; Smith et al. 2002; Wu et al. 2014). Therefore, allelic diversity in this candidate vaccine antigen is a potential constraint to the effectiveness of subunit vaccine use against coccidiosis in poultry.

\section{Conclusion}

Despite the key role poultry industry plays in the economy of each nation, the menace of coccidiosis has been a limiting factor. Though the fight against chicken coccidiosis has been on for several decades, the resurgence of this disease coupled with new variants among Eimeria parasite in different geographical areas demands a fresh attention on their control measures. The current methods of anticoccidial drugs, vaccines and strict management practice have proven effective but the emergence of genetic and antigenic diversity is a major threat on the effectiveness of the present anticoccidial vaccines and drugs. To design an effective vaccine, it is imperative to understand the dynamism in the evolution of diversity among genes that encodes potential vaccine antigens at the genome level along with the associated factors that drive this diversity. 
Acknowledgements Financial support by the National Research Foundation of South Africa (Grant Numbers: 112886 and 112768) is gratefully acknowledged.

\section{Compliance with ethical standards}

Conflict of interest The authors declare no conflicts of interest.

\section{References}

Ahmad TA, El-Sayed BA, El-Sayed LH (2016) Development of immunization trials against Eimeria spp. Trials Vaccinol $5: 38-47$

Anosa GN, Okoro OJ (2011) Anticoccidial activity of the methanolic extract of Musa paradisiaca root in chickens. Trop Anim Health Prod 43(1):245-248

Awad AM, El-Nahas AF, Abu-Akkada SS (2013) Evaluation of the protective efficacy of the anticoccidial vaccine Coccivac-B in broilers, when challenged with Egyptian field isolates of $E$. tenella. Parasitol Res 112(1):113-121

Bafundo KW, Cervantes HM, Mathis GF (2008) Sensitivity of Eimeria field isolates in the United States: responses of nicarbazin-containing anticoccidials. Poult Sci 87(9):1760-1767

Barkway CP, Pocock RL, Vrba V, Blake DP (2011) Loop-mediated isothermal amplification (LAMP) assays for the species-specific detection of Eimeria that infect chickens. BMC Vet Res 7(1):67

Belli SI, Smith NC, Ferguson DJ (2006) The coccidian oocyst: a tough nut to crack! Trends Parasitol 22(9):416-423

Blake D (2015) Eimeria genomics: where are we now and where are we going? Vet Parasitol 212:68-74

Blake DP, Tomley FM (2014) Securing poultry production from the ever-present Eimeria challenge. Trends Parasitol 30:12-19

Blake DP, Qin Z, Cai J, Smith AL (2008) Development and validation of real-time polymerase chain reaction assays specific to four species of Eimeria. Avian Pathol 37(1):89-94

Blake DP, Billington KJ, Copestake SL, Oakes RD, Quail MA, Wan KL, Shirley MW, Smith AL (2011) Genetic mapping identifies novel highly protective antigens for an apicomplexan parasite. PLoS Pathog 7(2):e1001279

Blake DP, Clark EL, Macdonald SE, Thenmozhi V, Kundu K, Garg R, Jatau ID, Ayoade S, Kawahara F, Moftah A, Reid AJ (2015) Population, genetic and antigenic diversity of the apicomplexan Eimeria tenella and their relevance to vaccine development. Proc Natl Acad Sci 112(38):E5343-E5350

Bozkurt M, Giannenas I, Küçükyilmaz K, Christaki E, Florou-Paneri P (2013) An update on approaches to controlling coccidia in poultry using botanical extracts. Br Poult Sci 54(6):713-727

Cantacessi C, Riddell S, Morris GM, Doran T, Woods WG, Otranto D, Gasser RB (2008) Genetic characterization of three unique operational taxonomic units of Eimeria from chickens in Australia based on nuclear spacer ribosomal DNA. Vet Parasitol 152(3):226-234

Carvalho FS, Wenceslau AA, Teixeira M, Albuquerque GR (2011) Molecular diagnosis of Eimeria species affecting naturally infected Gallus gallus. Genet Mol Res 10:996-1005

Castañón CA, Fraga JS, Fernandez S, Gruber A, Costa LDF (2007) Biological shape characterization for automatic image recognition and diagnosis of protozoan parasites of the genus Eimeria. Pattern Recogn 40(7):1899-1910

Chang CL, Yang CY, Muthamilselvan T, Yang WC (2016) Field trial of medicinal plant, Bidens pilosa, against eimeriosis in broilers. Sci Rep 6:24692

Chen CY, Chuang LT, Chiang YC, Lin CL, Lien YY, Tsen HY (2016) Use of a probiotic to ameliorate the growth rate and the inflammation of broiler chickens caused by Eimeria tenella infection. J Anim Res Nutr 1(2):1-7

Clark EL, Macdonald SE, Thenmozhi V, Kundu K, Garg R, Kumar S, Ayoade S, Fornace KM, Jatau ID, Moftah A, Nolan MJ (2016) Cryptic Eimeria genotypes are common across the southern but not northern hemisphere. Int J Parasitol 46(9):537-544

Cook SM, Higuchi DS, McGowan AL, Schrader JS, Withanage GSK, Francis MJ (2010) Polymerase chain reaction-based identity assay for pathogenic turkey Eimeria. Avian Dis 54(4):1152-1156

Dalloul RA, Lillehoj HS, Tamim NM, Shellem TA, Doerr JA (2005) Induction of local protective immunity to Eimeria acervulina by a Lactobacillus-based probiotic. Comp Immunol Microbiol Infect Dis 28(5-6):351-361

del Cacho E, Gallego M, Francesch M, Quílez J, Sánchez-Acedo C (2010) Effect of artemisinin on oocyst wall formation and sporulation during Eimeria tenella infection. Parasitol Int 59(4):506-511

Djezzar R, Benamirouche K, Baazize-Ammi D, Mohamed-Said R, Guetarni D (2014) Effect of a dietary supplementation combining a probiotic and a natural anticoccidial in broiler chickens. Afr J Agric Res 9(52):3782-3788

Drăgan L, Györke A, Ferreira JF, Pop IA, Dunca I, Drăgan M, Mircean V, Dan I, Cozma V (2014) Effects of Artemisia annua and Foeniculum vulgare on chickens highly infected with Eimeria tenella (Phylum Apicomplexa). Acta Vet Scand 56(1):22

Drew DR, Hodder AN, Wilson DW, Foley M, Mueller I, Siba PM, Dent AE, Cowman AF, Beeson JG (2012) Defining the antigenic diversity of Plasmodium falciparum apical membrane antigen 1 and the requirements for a multi-allele vaccine against malaria. PLoS ONE 7(12):e51023

Erb KH, Mayer A, Kastner T, Sallet KE, Haberl H (2012) The impact of industrial grain fed livestock production on food security: an extended literature review. Commissioned by compassion in world farming. The Tubney Charitable Trust and World Society for the Protection of Animals, London, UK

Etuk EB, Okoli IC, Uko MU (2004) Prevalence and management issues associated with poultry coccidiosis in Abak agricultural zone of Akwa Ibom state, Nigeria. Int J Poult Sci 3(2):135-139

Fernandez S, Costa AC, Katsuyama AM, Madeira AMBN, Gruber A (2003) A survey of the inter-and intraspecific RAPD markers of Eimeria spp. of the domestic fowl and the development of reliable diagnostic tools. Parasitol Res 89(6):437-445

Fornace KM, Clark EL, Macdonald SE, Namangala B, Karimuribo E, Awuni JA, Thieme O, Blake DP, Rushton J (2013) Occurrence of Eimeria species parasites on small-scale commercial chicken farms in Africa and indication of economic profitability. PLoS ONE 8(12):e84254

Gharekhani J, Sadeghi-Dehkordi Z, Bahrami M (2014) Prevalence of coccidiosis in broiler chicken farms in Western Iran. J Vet Medicine 2014:980604

Gholamrezaie Sani L, Mohammadi M, Jalali Sendi J, Abolghasemi SA, Roostaie Ali Mehr M (2013) Extract and leaf powder effect of Artemisia аппиа on performance, cellular and humoral immunity in broilers. Iran J Vet Res 14(1):15-20

Giannenas I, Tsalie E, Triantafillou E, Hessenberger S, Teichmann K, Mohnl M, Tontis D (2014) Assessment of probiotics supplementation via feed or water on the growth performance, intestinal morphology and microflora of chickens after experimental infection with Eimeria acervulina, Eimeria maxima and Eimeria tenella. Avian Pathol 43(3):209-216

Godwin RM, Morgan JAT (2015) A molecular survey of Eimeria in chickens across Australia. Vet Parasitol 214:16-21

Grumbles LC, Delaplane JP, Higgins TC (1948) Continuous feeding of low concentrations of sulfaquinoxaline for the control of coccidiosis in poultry. Poult Sci 27(5):605-608 
Györke A, Pop L, Cozma V (2013) Prevalence and distribution of Eimeria species in broiler chicken farms of different capacities. Parasite 20:50

Habibi H, Firouzi S, Nili H, Razavi M, Asadi SL, Daneshi S (2016) Anticoccidial effects of herbal extracts on Eimeria tenella infection in broiler chickens: in vitro and in vivo study. J Parasit Dis 40(2):401-407

Hafeez MA, Vrba V, Barta JR (2016) The complete mitochondrial genome sequence of Eimeria innocua (Eimeriidae, Coccidia, Apicomplexa). Mitochondrial DNA Part A 27(4):2805-2806

Hald T (2010) Analysis of the baseline survey on the prevalence of Campylobacter in broiler batches and of Campylobacter and Salmonella on broiler carcasses in the EU, 2008, Part A: Campylobacter and Salmonella prevalence estimates. European Food Safety Authority 2010

Hamidinejat H, Shapouri MS, Mayahi M, Borujeni MP (2010) Characterization of Eimeria species in commercial broilers by PCR based on ITS1 regions of rDNA. Iran J Parasitol 5(4):48

Haug A, Thebo P, Mattsson JG (2007) A simplified protocol for molecular identification of Eimeria species in field samples. Vet Parasitol 146(1):35-45

Haug A, Gjevre AG, Thebo P, Mattsson JG, Kaldhusdal M (2008) Coccidial infections in commercial broilers: epidemiological aspects and comparison of Eimeria species identification by morphometric and polymerase chain reaction techniques. Avian Pathol 37:161-170

He L, Zhou YQ, Oosthuizen MC, Zhao JL (2009) Loop-mediated isothermal amplification (LAMP) detection of Babesia orientalis in water buffalo (Bubalus babalis, Linnaeus, 1758) in China. Vet Parasitol 165(1):36-40

Healer J, Murphy V, Hodder AN, Masciantonio R, Gemmill AW, Anders RF, Cowman AF, Batchelor A (2004) Allelic polymorphisms in apical membrane antigen-1 are responsible for evasion of antibody-mediated inhibition in Plasmodium falciparum. Mol Microbiol 52(1):159-168

Huang J, Zhang Z, Li M, Song X, Yan R, Xu L, Li X (2015) Eimeria maxima microneme protein 2 delivered as DNA vaccine and recombinant protein induces immunity against experimental homogenous challenge. Parasitol Int 64(5):408-416

Jadhav BN, Nikam SV, Bhamre SN, Jaid EL (2011) Study of Eimeria necatrix in broiler chicken from Aurangabad District of Maharashtra state India. Int Multidiscip Res J 1(11):11-12

James S (1980) Thiamine uptake in isolated schizonts of Eimeria tenella and the inhibitory effects of amprolium. Parasitology 80(2):313-322

Jatau ID, Lawal IA, Kwaga JK, Tomley FM, Blake DP, Nok AJ (2016) Three operational taxonomic units of Eimeria are common in Nigerian chickens and may undermine effective molecular diagnosis of coccidiosis. BMC Vet Res 12(1):86

Jenkins MC, Miska K, Klopp S (2006) Application of polymerase chain reaction based on ITS1 rDNA to speciate Eimeria. Avian Dis 50(1):110-114

Jenkins MJ, Allen P, Wilkins G, Klopp S, Miska K (2008) Eimeria praecox infection ameliorates effects of Eimeria maxima infections in chickens. Vet Parasitol 155:10-14

Jenkins MC, Parker C, Klopp S, O'Brien C, Miska K, Fetterer R (2012) Gel-bead delivery of Eimeria oocysts protects chickens against coccidiosis. Avian Dis 56:306-309

Jiang L, Lin J, Han H, Dong H, Zhao Q, Zhu S, Huang B (2012) Identification and characterization of Eimeria tenella apical membrane antigen-1 (AMA1). PLoS ONE 7(7):e41115

Kaleem QM, Akhtar M, Awais MM, Saleem M, Zafar M, Iqbal Z, Muhammad F, Anwar MI (2014) Studies on Emblica officinalis derived tannins for their immunostimulatory and protective activities against coccidiosis in industrial broiler chickens. Sci World J 2014:378473
Karaer Z, Guven E, Akcay A, Kar S, Nalbantoglu S, Cakmak A (2012) Prevalence of subclinical coccidiosis in broiler farms in Turkey. Trop Anim Health Prod 44(3):589-594

Karanis P, Thekisoe O, Kiouptsi K, Ongerth J, Igarashi I, Inoue N (2007) Development and preliminary evaluation of a loopmediated isothermal amplification procedure for sensitive detection of Cryptosporidium oocysts in fecal and water samples. Appl Environ Microbiol 73(17):5660-5662

Kawahara F, Taira K, Nagai S, Onaga H, Onuma M, Nunoya T (2008) Detection of five avian Eimeria species by species-specific realtime polymerase chain reaction assay. Avian Dis 52(4):652-656

Kawahara F, Zhang G, Mingala CN, Tamura Y, Koiwa M, Onuma M, Nunoya T (2010) Genetic analysis and development of speciesspecific PCR assays based on ITS-1 region of rRNA in bovine Eimeria parasites. Vet Parasitol 174:49-57

Kirkpatrick NC, Blacker HP, Woods WG, Gasser RB, Noormohammadi AH (2009) A polymerase chain reaction-coupled highresolution melting curve analytical approach for the monitoring of monospecificity of avian Eimeria species. Avian Pathol 38(1):13-19

Kumar S, Garg R, Moftah A, Clark EL, Macdonald SE, Chaudhry AS, Sparagano O, Banerjee PS, Kundu K, Tomley FM, Blake DP (2014) An optimised protocol for molecular identification of Eimeria from chickens. Vet Parasitol 199:24-31

Kumar S, Garg R, Banerjee PS, Ram H, Kundu K, Kumar S, Mandal M (2015) Genetic diversity within ITS-1 region of Eimeria species infecting chickens of north India. Infect Genet Evol 36:262-267

Lal K, Bromley E, Oakes R, Prieto JH, Sanderson SJ, Kurian D et al (2009) Proteomic comparison of four Eimeria tenella life-cycle stages: unsporulated oocyst, sporulated oocyst, sporozoite and second-generation merozoite. Proteomics 9(19):4566-4576

Lalonde LF, Gajadhar AA (2011) Detection and differentiation of coccidian oocysts by real-time PCR and melting curve analysis. J Parasitol 97(4):725-730

Lee S, Lillehoj HS, Park DW, Hong YH, Lin JJ (2007) Effects of Pediococcus- and Saccharomyces-based probiotic (MitoMax) on coccidiosis in broiler chickens. Comp Immunol Microbiol Infect Dis 30(4):261-268

Lee JT, Broussard C, Fitz-Coy S, Burke P, Eckert NH, Stevens SM, Anderson PN, Anderson SM, Caldwell DJ (2009) Evaluation of live oocyst vaccination or salinomycin for control of field-strain Eimeria challenge in broilers on two different feeding programs. J Appl Poult Res 18(3):458-464

Lee BH, Kim WH, Jeong J, Yoo J, Kwon YK, Jung BY, Kwon JH, Lillehoj HS, Min W (2010) Prevalence and cross-immunity of Eimeria species on Korean chicken farms. J Vet Med Sci 72(8):985-989

Lew AE, Anderson GR, Minchin CM, Jeston PJ, Jorgensen WK (2003) Inter-and intra-strain variation and PCR detection of the internal transcribed spacer 1 (ITS-1) sequences of Australian isolates of Eimeria species from chickens. Vet Parasitol 112(1):33-50

Lim LS, Tay YL, Alias H, Wan KL, Dear PH (2012) Insights into the genome structure and copy-number variation of Eimeria tenella. BMC Genom 13(1):389

Long PL, Joyner LP (1984) Problems in the identification of species of Eimeria. J Eukaryot Microbiol 31(4):535-541

Mai K, Sharman PA, Walker RA, Katrib M, Souza DD, McConville MJ, Wallach MG, Belli SI, Ferguson DJ, Smith NC (2009) Oocyst wall formation and composition in coccidian parasites. Mem Inst Oswaldo Cruz 104(2):281-289

Malatji DP, Tsotetsi AM, van Marle-Köster E, Muchadeyi FC (2016) A description of village chicken production systems and prevalence of gastrointestinal parasites: case studies in Limpopo 
and KwaZulu-Natal provinces of South Africa. Onderstepoort J Vet Res 83(1):1-8

Mathis GF, Newman LJ, Fitz-Coy S, Lumpkins B, Charette R, Fuller L (2017) Comparison of breeder/layer coccidiosis vaccines: part 1-precocity and pathogenicity. J Appl Poult Res 27(1):33-37

Milbradt EL, Mendes AL, Ferreira JG, Almeida Paz I, Martins MB, Sanfelice C et al (2014) Use of live oocyst vaccine in the control of turkey coccidiosis: effect on performance and intestinal morphology. J Appl Poult Res 23:204-211

Mohammed BR, Sunday OS (2015) An overview of the prevalence of avian coccidiosis in poultry production and its economic importance in Nigeria. Vet Res 3(3):35-45

Morgan JA, Godwin RM (2017) Mitochondrial genomes of Australian chicken Eimeria support the presence of ten species with low genetic diversity among strains. Vet Parasitol 243:58-66

Morris GM, Woods WG, Richards DG, Gasser RB (2007) Investigating a persistent coccidiosis problem on a commercial broilerbreeder farm utilising PCR-coupled capillary electrophoresis. Parasitol Res 101(3):583-589

Mottet A, Tempio G (2017) Global poultry production: current state and future outlook and challenges. World's Poult Sci J 73(2):245-256

Muazu A, Masdooq AA, Ngbede J, Salihu AE, Haruna G, Habu AK, Sati MN, Jamilu H (2008) Prevalence and identification of species of Eimeria causing coccidiosis in poultry within Vom, Plateau State, Nigeria. Int J Poult Sci 7(9):917-918

Musa IW, Sa'idu L, Jatau JT, Adamu J, Otu MO, Abdu PA (2010) Outbreak of coccidiosis in 5-day old commercial breeder flock IN Zaria, Nigeria. Int J Poult Sci 9(12):1112-1115

Naidoo V, McGaw LJ, Bisschop SP, Duncan N, Eloff JN (2008) The value of plant extracts with antioxidant activity in attenuating coccidiosis in broiler chickens. Vet Parasitol 153(3-4):214-219

Nematollahi A, Moghaddam GH, Niyazpour F (2008) Prevalence of Eimeria spp. among broiler chicks in Tabriz (Northwest of Iran). Res J Poult Sci 2(3):72-74

Nghonjuyi NW, Tiambo CK, Kimbi HK, Manka'a CN, Juliano RS, Lisita F (2015) Efficacy of ethanolic extract of Carica papaya leaves as a substitute of sulphanomide for the control of coccidiosis in KABIR chickens in Cameroon. J Anim Health Prod 3(1):21-27

Ogedengbe JD, Hanner RH, Barta JR (2011) DNA barcoding identifies Eimeria species and contributes to the phylogenetics of coccidian parasites (Eimeriorina, Apicomplexa, Alveolata). Int J Parasitol 41(8):843-850

Ogedengbe ME, El-Sherry S, Ogedengbe JD, Chapman HD, Barta JR (2018) Phylogenies based on combined mitochondrial and nuclear sequences conflict with morphologically defined genera in the eimeriid coccidia (Apicomplexa). Int $\mathrm{J}$ Parasitol 48(1):59-69

Ola-Fadunsin SD, Ademola IO (2013) Direct effects of Moringa oleifera Lam (Moringaceae) acetone leaf extract on broiler chickens naturally infected with Eimeria species. Trop Anim Health Prod 45(6): 1423-1428

Oliveira UC, Fraga JS, Licois D, Pakandl M, Gruber A (2011) Development of molecular assays for the identification of the 11 Eimeria species of the domestic rabbit (Oryctolagus cuniculus). Vet Parasitol 176(2):275-280

Oljira D, Melaku A, Bogale B (2012) Prevalence and risk factors of coccidiosis in poultry farms in and around Ambo Town, Western Ethiopia. Am Eurasian J Sci Res 7(4):146-149

Peek HW, Landman WJ (2011) Coccidiosis in poultry: anticoccidial products, vaccines and other prevention strategies. Vet Q 31(3):143-161

Pegg E, Doyle K, Clark EL, Jatau ID, Tomley FM, Blake DP (2016) Application of a new PCR-RFLP panel suggests a restricted population structure for Eimeria tenella in UK and Irish chickens. Vet Parasitol 229:60-67

Poulsen J, Permin A, Hindsbo O, Yelifari L, Nansen P, Bloch P (2000) Prevalence and distribution of gastro-intestinal helminths and haemoparasites in young scavenging chickens in upper eastern region of Ghana, West Africa. Prev Vet Med 45(3-4):237-245

Prakashbabu BC, Thenmozhi V, Limon G, Kundu K, Kumar S, Garg R, Clark EL, Rao AS, Raj DG, Raman M, Banerjee PS (2017) Eimeria species occurrence varies between geographic regions and poultry production systems and may influence parasite genetic diversity. Vet Parasitol 233:62-72

Quiroz-Castañeda RE, Dantán-González E (2015) Control of avian coccidiosis: future and present natural alternatives. BioMed Res Int 2015:430610

Rathinam T, Gadde U, Chapman HD (2015) Molecular detection of field isolates of Turkey Eimeria by polymerase chain reaction amplification of the cytochrome c oxidase I gene. Parasitol Res 114(7):2795-2799

Ritzi MM, Abdelrahman W, Mohnl M, Dalloul RA (2014) Effects of probiotics and application methods on performance and response of broiler chickens to an Eimeria challenge. Poult Sci 93(11):2772-2778

Ritzi MM, Abdelrahman W, Van-Heerden K, Mohnl M, Barrett NW, Dalloul RA (2016) Combination of probiotics and coccidiosis vaccine enhances protection against an Eimeria challenge. Vet Res 47(1): 111

Rogers EF, Clark RL, Becker HJ, Pessolano AA, Leanza WJ, McManus EC, Andriuli FL, Cuckler AC (1964) Antiparasitic drugs V. Anticoccidial activity of 4-amino-2-theoxybenzoic acid and related compounds. Proc Soc Exp Biol Med 117:488-492

Sandhu BS, Brar RS, Brar APS, Sood NK, Singla LD (2009) Prevalence and pathology of parasitic gastrointestinal infections of poultry in Punjab. Indian Vet J 86:1276-1277

Schwarz RS, Jenkins MC, Klopp S, Miska KB (2009) Genomic analysis of Eimeria spp. populations in relation to performance levels of broiler chicken farms in Arkansas and North Carolina. J Parasitol 95(4):871-880

Sharma S, Iqbal A, Azmi S, Shah HA (2009) Study of poultry coccidiosis in organized and backyard farms of Jammu region. Environment 43:1601-1604

Shirley MW (1992) Research on avian coccidia: an update. Br Vet J 148(6):479-499

Shirley MW, Smith AL, Tomley FM (2005) The biology of avian Eimeria with an emphasis on their control by vaccination. Adv Parasitol 60:285-330

Shivaramaiah C, Barta JR, Hernandez-Velasco X, Téllez G, Hargis B (2014) Coccidiosis: recent advancements in the immunobiology of Eimeria species, preventive measures, and the importance of vaccination as a control tool against these Apicomplexan parasites. Vet Med 5(5):23-34

Singla LD, Gupta SK (2012) Advances in diagnosis of coccidiosis in poultry. In: Gupta RP, Garg SR, Nehra V, Lather D (eds) Veterinary diagnostics: current trends. Satish Serial Publishing House, Delhi, pp 615-628

Smith CK, Galloway RB (1983) Influence of monensin on cation influx and glycolysis of Eimeria tenella sporozoites in vitro. J Parasitol 69(4):666-670

Smith AL, Hesketh P, Archer A, Shirley MW (2002) Antigenic diversity in Eimeria maxima and the influence of host genetics and immunization schedule on cross-protective immunity. Infect Immun 70(5):2472-2479

Song X, Gao Y, Xu L, Yan R, Li X (2015a) Partial protection against four species of chicken coccidia induced by multivalent subunit vaccine. Vet Parasitol 212(3):80-85 
Song X, Ren Z, Yan R, Xu L, Li X (2015b) Induction of protective immunity against Eimeria tenella, Eimeria necatrix, Eimeria maxima and Eimeria acervulina infections using multivalent epitope DNA vaccines. Vaccine 33(24):2764-2770

Stringfellow K, Caldwell D, Lee J, Mohnl M, Beltran R, Schatzmayr G, Fitz-Coy S, Broussard C, Farnell M (2011) Evaluation of probiotic administration on the immune response of coccidiosisvaccinated broilers. Poult Sci 90(8):1652-1658

Sultana R, Maqbool A, Ahmad MZ, Iqbal Ch Z (2017) Chemotherapy of coccidiosis in calves. Arch Vet Sci Technol: AVST-129(6)

Sun XM, Ji YS, Liu XY, Xiang M, He G, Xie L, Suo JX, Suo X (2017) Improvement and evaluation of loop-mediated isothermal amplification for rapid detection of Toxoplasma gondii infection in human blood samples. PLoS ONE 12(1):e0169125

Tan L, Li Y, Yang X, Ke Q, Lei W, Mughal MN, Fang R, Zhou Y, Shen B, Zhao J (2017) Genetic diversity and drug sensitivity studies on Eimeria tenella field isolates from Hubei Province of China. Parasites Vectors 10(1):137

Thekisoe OM, Rambritch NE, Nakao R, Bazie RS, Mbati P, Namangala B et al (2010) Loop-mediated isothermal amplification (LAMP) assays for detection of Theileria parva infections targeting the PIM and p150 genes. Int J Parasitol 40(1):55-61

Thenmozhi V, Veerakumari L, Raman M (2014) Preliminary genetic diversity study on different isolates of Eimeria tenella from South India. Int J Adv Vet Sci Technol 3(1):114-118

UN DESA (2017) World Population Prospects: the 2017 Revision. https://www.un.org/development/desa/en/news/population/worldpopulation-prospects-2017.html. Accessed 10 Apr 2018
Vrba V, Blake DP, Poplstein M (2010) Quantitative real-time PCR assays for detection and quantification of all seven Eimeria species that infect the chicken. Vet Parasitol 174(3):183-190

Wang CC (1976) Inhibition of the respiration of Eimeria tenella by quinolone coccidiostats. Biochem Pharmacol 25(3):343-349

Wang CC (1978) Biochemical and nutritional aspects of coccidia. Pages 135-184 in Avian Coccidiosis. In: Long PL, Boorman KN, Freeman BM (eds) Proceedings of the 13th Poultry Science Symposium. British Poultry Science Ltd., Edinburgh, UK

Wong DT, Horng JS, Wilkinson JR (1972) Robenidine, an inhibitor of phosphorylation. Biochem Biophys Res Commun 46:621-627

Wu LL, Lin RQ, Sun MF, Liu LD, Duan WF, Zou SS, Yuan ZG, Weng YB (2014) Biological characteristics of Chinese precocious strain of Eimeria acervulina and its immune efficacy against different field strains. Avian Dis 58(3):367-372

Yim D, Kang SS, Kim DW, Kim SH, Lillehoj HS, Min W (2011) Protective effects of Aloe vera-based diets in Eimeria maximainfected broiler chickens. Exp Parasitol 127(1):322-325

Yin G, Lin Q, Qiu J, Qin M, Tang X, Suo X, Huang Z, Liu X (2015) Immunogenicity and protective efficacy of an Eimeria vaccine candidate based on Eimeria tenella immune mapped protein 1 and chicken CD40 ligand. Vet Parasitol 210(1):19-24

Zhao X, Duszynski DW, Loker ES (2001) A simple method of DNA extraction for Eimeria species. J Microbiol Methods 44(2):131-137 